\title{
Fertilizer Concentration and Leaching Affect Nitrate-Nitrogen Leaching from Potted Poinsettia
}

\author{
Mark V. Yelanich ${ }^{1}$ and John A. Biernbaum ${ }^{2}$ \\ Department of Horticulture, Michigan State University, East Lansing, \\ MI 48824-1325
}

Additional index words. Euphorbia pulcherrima, irrigation, leaching fraction, soluble salts

\begin{abstract}
The influence of fertilizer concentration and leaching volume on the quantity of applied $\mathrm{N}$ and water that were leached from a container-grown poinsettia crop (Euphorbia pulcherrima Willd.) was investigated. The $\mathrm{NO}_{3}-\mathrm{N}$ quantity leached after 71 days increased with higher $\mathrm{NO}_{3}-\mathrm{N}$ application rates $\left(7,14\right.$, or $\left.28 \mathrm{~mol} \mathrm{NO}_{3}-\mathrm{N} / \mathrm{m}^{3}\right)$ and higher leaching volumes; it ranged from $0.03 \mathrm{~g} \mathrm{NO}_{3}-\mathrm{N}$ [ $7 \mathrm{~mol} \cdot \mathrm{m}^{-3}, 0.00$ container capacity leached (CCL)] to $7.65 \mathrm{~g} \mathrm{NO}_{3}-\mathrm{N}\left(28 \mathrm{~mol} \cdot \mathrm{m}^{-3}, 1.0 \mathrm{CCL}\right)$. The $\mathrm{NO}_{3}-\mathrm{N}$ concentration for saturated media extracts increased with lower leaching volumes and higher fertilizer concentrations. For example, when $7 \mathrm{~mol} \mathrm{NO}_{3}-\mathrm{N} / \mathrm{m}^{3}$ was applied, $\mathrm{NO}_{3}-\mathrm{N}$ in the medium was $27.1 \mathrm{~mol} \mathrm{NO}_{3}-\mathrm{N} /$ $\mathrm{m}^{3}$ when $0 \mathrm{CCL}$ was used, but it was $8.6 \mathrm{~mol} \mathrm{NO}-\mathrm{N} / \mathrm{m}^{3}$ when $1.0 \mathrm{CCL}$ was used. Shoot height and dry mass were not affected by the treatments. Leaching treatments also did not influenced leaf area, but leaf area was larger at 7 compared to 14 or $28 \mathrm{~mol} \mathrm{NO}_{3}-\mathrm{N} / \mathrm{m}^{3}$.
\end{abstract}

Leaching fraction (LF) and fertilizer concentration (FC) influence the nutrient concentrations in a peat-based medium for containergrown plants. Different combinations of FC and $\mathrm{LF}$ can yield similar medium $\mathrm{N}$ concentrations, even though varying $\mathrm{N}$ amounts are applied (Yelanich and Biernbaum, 1993). Leachate electrical conductivity (EC) also increases over time with lower leaching volumes (Ku and Hershey, 1991). Neither Yelanich and Biernbaum nor Ku and Hershey measured $\mathrm{NO}_{3}$ effluent, an important consideration in determining fertilization method efficiency. A more accurate measurement of $\mathrm{NO}_{3}-\mathrm{N}$ lost from container-grown plants is necessary to evaluate the potential for $\mathrm{NO}_{3}-\mathrm{N}$ runoff from greenhouses. Our objective was to evaluate the effects of leaching volume and fertilizer concentration on the quantity of $\mathrm{NO}_{3}$ - $\mathrm{N}$ leached, media nutrient concentration, and vegetative growth of poinsettia.

\section{Materials and Methods}

The design was a randomized complete block, with four blocks selected for initial plant size. Plants were placed randomly on one bench in a well-ventilated glass greenhouse with cement floors and constant air circula-

Received for publication 16 Dec. 1993. Accepted for publication $14 \mathrm{Feb}$. 1994. We acknowledge Michigan State Agricultural Expt. Station(MSAES) and the American Floral Endowment for supporting this research. W.R. Grace Co., Fogelsville, Pa., provided plant tissue analysis. The use of trade names in this publication does not imply product endorsement by the MSAES. The cost of publishing this paper was defrayed in part by the payment of page charges. Under postal regulations, this paper therefore must be hereby marked advertisement solely to indicate this fact.

${ }^{1}$ Graduate Research Assistant.

${ }^{2}$ Associate Professor. tion. Rooted cuttings of 'V-14 Glory' poinsettia were planted on 2 Apr. 1990 and kept vegetative during the experiment. The root medium, a commercial mix of peat, course vermiculite, perlite, and a complete nutrient charge (Baccto Professional Grower's Mix; Michigan Peat Co., Houston), was placed in a $11.5-\mathrm{cm}$-tall pot with a $12-\mathrm{cm}$-wide top and a total volume of $1271 \mathrm{~cm}^{3}$. The medium had an initial container capacity of $841 \mathrm{~cm}^{3}$, a bulk density of $0.17 \mathrm{~g} \cdot \mathrm{cm}^{-3}$, and an air porosity of $0.19 \mathrm{~cm}^{3} \cdot \mathrm{cm}^{-3}$. Container capacity of the medium was determined by placing the pot plus the medium in a water-tight container and slowly saturating the pot from the bottom. The medium was allowed to equilibrate for $12 \mathrm{~h}$; then the medium plus the pot were weighed at saturation, after draining for $0.5 \mathrm{~h}$ and after oven-drying at $60 \mathrm{C}$ for 2 days. The drained weight subtracted from the oven dry weight is the container capacity volume (water density $=1 \mathrm{~g} \mathrm{H}_{2} \mathrm{O} / \mathrm{cm}^{3}$ ). The medium had an initial EC of $1.38 \mathrm{dS} \cdot \mathrm{m}^{-1}$ and a $\mathrm{pH}$ of 5.9 . The irrigation water had an EC of 0.6 to $0.7 \mathrm{dS} \cdot \mathrm{m}^{-1}$ and an alkalinity of 300 to $315 \mathrm{mg} \mathrm{CaCO}_{3} /$ liter (6.0 to $\left.6.3 \mathrm{~mol} \cdot \mathrm{m}^{-3}\right)$. The three nutrient solutions were prepared using $\mathrm{Ca}\left(\mathrm{NO}_{3}\right)_{2}$ and $\mathrm{KNO}_{3}$ and contained $\mathrm{NO}_{3}-\mathrm{N}$ at 7,14 , or $28 \mathrm{~mol} \cdot \mathrm{m}^{-3}\left(\mathrm{~mol} \cdot \mathrm{m}^{-3}=\right.$ mmol-liter ${ }^{-1}=\mathrm{mm} ; \mathrm{mol} \mathrm{NO}_{3}-\mathrm{N} / \mathrm{m}^{3} \times 14=\mathrm{ppm}$ $\mathrm{NO}_{3}-\mathrm{N}$ ) and $\mathrm{K}$ at 3,6 , or $12 \mathrm{~mol} \cdot \mathrm{m}^{-3}$, respectively. Phosphorous was supplied as superphosphate in the root medium. Pots were weighed daily and irrigated when they weighed $<0.65 \mathrm{~kg}$, which corresponded to $55 \%$ of container capacity. Leaching occurred at this weight after we had applied 0.28 liters of solution. The nutrient solutions were applied in 250-ml aliquots from a beaker to the center of the pot. The five leaching treatments were determined by adding increasing amounts of solution to pots and measuring the volume of leachate. We determined that $0.25,0.5,0.75$, 1.0 , and 1.25 liters of solution were necessary to achieve $0,0.25,0.5,0.75$, and 1.0 container capacities leached (CCL). These leaching volumes resulted in leaching fractions of $0,0.4$, $0.5,0.6$, and 0.7 , respectively. The term CCL was used instead of leaching fraction because it relates the leachate volume to the medium used instead of the volume applied. The pots were weighed before and after each irrigation, and the leachate volume and $\mathrm{NO}_{3}-\mathrm{N}$ concentration were determined. The leachate volume changed little during the experiment, so the volume of solutions applied was not modified. After 71 days, the total quantity of water and Nleached was calculated for each plant. Nitrogen leaching is reported for 0 CCL treatments because small volumes of leaching (averaged over the entire experiment at $11 \mathrm{ml}$ ) did occur at high concentrations. The total percentage of $\mathrm{NO}_{3}-\mathrm{N}$ and water leached was calculated by taking the total leachate divided by the total applied. The percentage of $\mathrm{NO}_{3}-\mathrm{N}$ and water leached was described by the following equation: water or $\mathrm{N}$ leached $(\%)=(\mathrm{CCL} \times 100) \div$ $\left(C C L+b_{1}\right)$. The CCL needed to remove $50 \%$ of the water or $\mathrm{N}$ applied corresponds to $\mathrm{b}_{1}$.

After 71 days, the top $2.5 \mathrm{~cm}$ of medium was removed and the root zone analyzed for $\mathrm{NO}_{3}-\mathrm{N}$ concentration using the saturated media extract (Warncke, 1986). Nitrate-nitrogen was determined using an ion-specific electrode (Orion Research, Boston). Shoot height, number of leaves, leaf area as determined by a leaf area meter (Delta-T Devices, Cambridge, England), and total fresh mass also were determined. Shoot dry mass was determined after

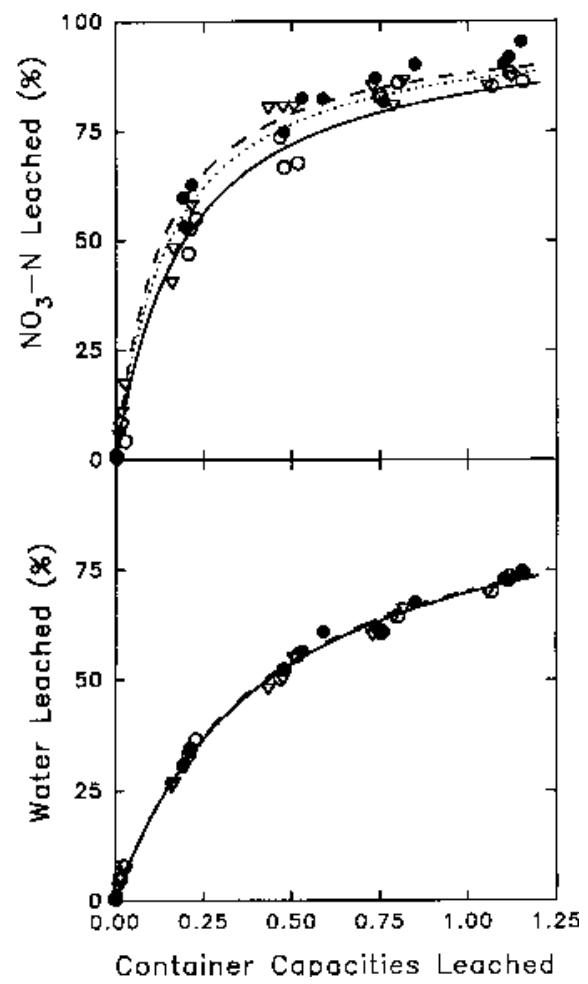

Fig. 1. Effect of fertilizer concentration applied and container capacities leached (CCL) on the percentage of $\mathrm{NO}_{3}-\mathrm{N}$ leached (top) and water leached (bottom) from poinsettia pots : $\bigcirc$ and $\longrightarrow=7 \mathrm{~mol} \mathrm{~N} / \mathrm{m}^{3}$, and $-=14 \mathrm{~mol} \mathrm{~N} / \mathrm{m}^{3}$, $\nabla$ and $\cdots \cdots=28 \mathrm{~mol} \mathrm{~N} / \mathrm{m}^{3}$. 
drying plants in a forced-draft oven at $60 \mathrm{C}$ for 4 days. The entire dried shoot was ground and analyzed for total $\mathrm{N}$.

\section{Results and Discussion}

The concentration of $\mathrm{NO}_{3}-\mathrm{N}$ in the leachate was constant from week 2 to week 10, except for $0.25 \mathrm{CCL}$ at 14 and $28 \mathrm{~mol} \mathrm{~N} / \mathrm{m}^{3}$ (data not shown). The total percentage of water and $\mathrm{NO}_{3}-\mathrm{N}$ leached after 71 days increased as higher CCLs were used. There was little difference between the three FCs in the percentage of water leached (Fig. 1). When $\mathrm{NO}_{3}-\mathrm{N}$ at 7,14 , or $28 \mathrm{~mol} \cdot \mathrm{m}^{-3}$ was applied, the differences in $b_{1}$ values were relatively minor, although the $b_{1}$ for $7 \mathrm{~mol} \cdot \mathrm{m}^{-3}$ was higher than the other two (Table 1). The percentage of water and $\mathrm{NO}_{3}-\mathrm{N}$ leached per CCL decreased when CCL was $>0.5$ (Fig. 1). The percentage of $\mathrm{NO}_{3}-\mathrm{N}$ leached at each $\mathrm{CCL}$ was higher than the percentage of water leached. The quantity of $\mathrm{NO}_{3}-\mathrm{N}$ leached ranged from 0.48 to $7.65 \mathrm{~g} /$

Table 1. Coefficients for the equation predicting the percentage of applied $\mathrm{N}$ and water leached. Upper and lower 95\% confidence intervals in parenthesis.

\begin{tabular}{|c|c|c|}
\hline $\begin{array}{l}\mathrm{NO}_{3}-\mathrm{N} \\
\left(\mathrm{mol} \cdot \mathrm{m}^{-3}\right)\end{array}$ & $\begin{array}{c}\text { N leached } \\
b_{1}{ }^{2}\end{array}$ & $\begin{array}{c}\text { Water leached } \\
b_{1}\end{array}$ \\
\hline 7 & $0.19 \mathrm{a}(0.17-0.22)^{\mathrm{y}}$ & $0.43 \mathrm{a}(0.41-0.45)$ \\
\hline 14 & $0.13 \mathrm{~b}(0.12-0.15)$ & $0.42 \mathrm{a}(0.41-0.43)$ \\
\hline 28 & 0.15 b (0.13-0.17) & $0.43 \mathrm{a}(0.42-0.45)$ \\
\hline \multicolumn{3}{|c|}{$\begin{array}{l}{ }^{2} b_{1}=\text { Container capacities leached that are needed to } \\
\text { remove } 50 \% \text { of the } \mathrm{N} \text { or water applied. } \\
\text { y Equation coefficients (in columns) followed by the } \\
\text { same letter are not significantly different by } t \text { test at } \\
P \leq 0.05 \text {. }\end{array}$} \\
\hline
\end{tabular}
plant (Table 2).

The concentration of $\mathrm{NO}_{3}-\mathrm{N}$ in the root medium was highest when the highest $\mathrm{NO}_{3}-\mathrm{N}$ concentration was applied and leaching was minimized (Fig. 2). There seemed to be little benefit in leaching $>0.75 \mathrm{CCL}$ to reduce $\mathrm{NO}_{3}-\mathrm{N}$ in the medium, especially at lower FC.

There were no significant treatment effects on height, lateral shoot count (data not presented), or total shoot dry mass (Table 2). Fresh mass was highest with no leaching at 7 molNO ${ }_{3}-\mathrm{N} / \mathrm{m}^{3}$, but was higher with $0.25 \mathrm{CCL}$ at $14 \mathrm{~mol} \mathrm{NO}-\mathrm{N} / \mathrm{m}^{3}$ and $0.5 \mathrm{CCL}$ at $28 \mathrm{~mol}$ $\mathrm{NO}_{3}-\mathrm{N} / \mathrm{m}^{3}$. Nitrogen concentration in the shoot tissue mostly decreased at higher CCL.

The percentage of applied $\mathrm{NO}_{3}-\mathrm{N}$ leached from the medium exceeded the percentage of water leached. The concentration of salt in the leachate of nonplanted systems is determined by the amount of salt in the medium, the amount of mixing occurring in the medium, the volume of leachate, the adsorption by the medium, and the concentration of the applied solution (Wagenet, 1983). Kerr and Hanan (1985) demonstrated that the amount of salt mixing that occurs is a function of the physical properties of the media. If our medium had had a higher percolation rate (i.e., less mixing), a lower percentage of $\mathrm{NO}_{3}-\mathrm{N}$ would have been leached. Conversely, more $\mathrm{N}$ might have been leached if we had used a medium with a slower percolation rate (i.e., more mixing).

After 71 days, the medium $\mathrm{NO}_{3}-\mathrm{N}$ concentrations were similar when CCLs were at $>0.5$, indicating that $\mathrm{NO}_{3}-\mathrm{N}$ was not accumulating in the medium (Fig. 2). This result is similar to what we have found in previous studies (Yelanich and Biernbaum, 1993) in which there was little increase in medium $\mathrm{NO}_{3}-\mathrm{N}$ over time with 0.68 CCL. We used lower CCL

Table 2. Poinsettia vegetative growth characteristics, leaf $\mathrm{N}$ concentration, and quantity of $\mathrm{N}$ leached 71 days after planting for container capacities leached (CCL) of $0,0.25,0.50,0.75$, and 1.00 and fertilizer concentrations (FC) of 7, 14, or $28 \mathrm{~mol} \mathrm{NO}_{3}-\mathrm{N} / \mathrm{m}^{3}$.

\begin{tabular}{|c|c|c|c|c|c|}
\hline \multirow[b]{2}{*}{$\mathrm{CCL}$} & \multicolumn{3}{|c|}{ Shoot } & \multirow[b]{2}{*}{$\begin{array}{l}\text { Leaf area } \\
\qquad\left(\mathrm{m}^{2}\right)\end{array}$} & \multirow[b]{2}{*}{$\begin{array}{c}\mathrm{NO}_{3}-\mathrm{N} \text { leached } \\
\text { (g/plant) }\end{array}$} \\
\hline & $\begin{array}{l}\text { Fresh mass } \\
(\mathrm{g})\end{array}$ & $\begin{array}{l}\text { Dry mass } \\
(\mathrm{g})\end{array}$ & $\begin{array}{c}\mathrm{N} \\
(\mathrm{g} \mathrm{N} / 100 \mathrm{~g} \text { dry mass) }\end{array}$ & & \\
\hline \multicolumn{6}{|c|}{$F C=7 \mathrm{~mol} \mathrm{NO}_{3}-\mathrm{N} / \mathrm{m}^{3}$} \\
\hline 0.00 & 63.0 & 10.80 & 3.8 & 0.24 & 0.03 \\
\hline 0.25 & 55.0 & 9.35 & 3.9 & 0.19 & 0.48 \\
\hline 0.50 & 55.4 & 9.60 & 3.2 & 0.20 & 0.98 \\
\hline 0.75 & 53.9 & 9.42 & 3.2 & 0.19 & 1.59 \\
\hline 1.00 & 43.4 & 7.52 & 3.3 & 0.14 & 1.85 \\
\hline \multicolumn{6}{|c|}{$\mathrm{FC}=14 \mathrm{~mol} \mathrm{NO}_{3}-\mathrm{N} / \mathrm{m}^{3}$} \\
\hline 0.00 & 49.0 & 9.17 & 3.8 & 0.17 & 0.00 \\
\hline 0.25 & 57.8 & 10.24 & 3.8 & 0.21 & 1.12 \\
\hline 0.50 & 50.3 & 8.58 & 3.2 & 0.18 & 2.25 \\
\hline 0.75 & 53.2 & 9.23 & 3.8 & 0.19 & 2.98 \\
\hline 1.00 & 48.0 & 8.58 & 2.9 & 0.16 & 4.11 \\
\hline \multicolumn{6}{|c|}{$F C=28 \mathrm{~mol} \mathrm{NO}_{3}-\mathrm{N} / \mathrm{m}^{3}$} \\
\hline 0.00 & 36.0 & 7.21 & 4.0 & 0.12 & 0.23 \\
\hline 0.25 & 46.1 & 8.47 & 4.1 & 0.16 & 1.39 \\
\hline 0.50 & 60.3 & 11.20 & 3.6 & 0.18 & 4.22 \\
\hline 0.75 & 59.8 & 10.61 & 3.7 & 0.20 & 6.41 \\
\hline 1.00 & 40.4 & 7.68 & 3.7 & 0.14 & 7.65 \\
\hline $\mathrm{FC}$ & NS & NS & NS & $*$ & $* * *$ \\
\hline CCL & $*$ & NS & $*$ & NS & $* * *$ \\
\hline $\mathrm{FC} \times \mathrm{CCL}$ & $*$ & NS & NS & NS & $* * *$ \\
\hline
\end{tabular}

Ns, *,*** Nonsignificant or significant at $P \leq 0.05$ or 0.001 , respectively.

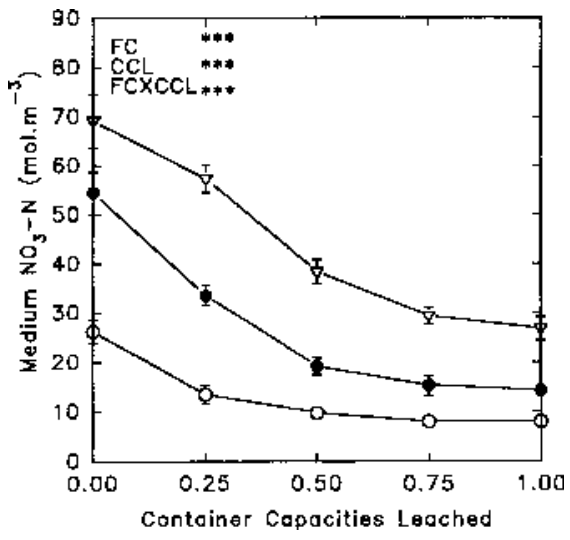

Fig. 2. Effect of fertilizer concentration (FC) applied and container capacities leached (CCL) on the concentration of $\mathrm{NO}_{3}-\mathrm{N}$ in the medium 71 days after planting poinsettias: $\bigcirc=7 \mathrm{~mol} \mathrm{~N} / \mathrm{m}^{3}, \mathbf{O}=$ $14 \mathrm{~mol} \mathrm{~N} / \mathrm{m} 3, \nabla=28 \mathrm{~mol} \mathrm{~N} / \mathrm{m}^{3}$.

than Kerr and Hanan (1985). They needed CCL at $>3$ or $>5$ for $90 \%$ salt removal. In our experiment, the lack of $\mathrm{NO}_{3}-\mathrm{N}$ accumulation in the medium with CCL between 0.5 and 1 is probably due to the plant's uptake of $\mathrm{NO}_{3}-\mathrm{N}$ from the medium or greater salt mixing in nonsaturated pots and therefore greater salt removal.

Our vegetative poinsettias grew at half the recommended $\mathrm{N}$ concentration rate of 14 $\mathrm{mol} \cdot \mathrm{m}^{-3}$ (Ecke et al., 1990) and without leaching. Our results are similar to those that we obtained in a previous experiment (Yelanich and Biernbaum, 1993) in which adequate medium $\mathrm{N}$ concentrations could be obtained with $7 \mathrm{~mol} \mathrm{NO} \mathrm{N}_{3}-\mathrm{N} / \mathrm{m}^{3}$. However, $>50 \%$ of the applied $\mathrm{NO}_{3}-\mathrm{N}$ could be lost regardless of the $\mathrm{FC}$ used at leaching volumes of 0.25 CCL.

\section{Literature Cited}

Ecke, P.E., O.A. Matkin, and D.E. Hartley. 1990. The poinsettia manual, 3rd ed. Paul Ecke Poinsettia, Encinitas, Calif.

Kerr, G.P. and J.J. Hanan. 1985. Leaching of container media. J. Amer. Soc. Hort. Sci. 110:474480.

Ku, C.S.M. and D.R. Hershey. 1991. Leachate electrical conductivity and growth of potted poinsettias with leaching fractions of 0 to 0.4 . J. Amer. Soc. Hort. Sci. 116:802-806.

Wagenet, R.J. 1983. Principle of salt movement in soils, p. 123-140. In: D.W. Nelson et al. (eds.). Chemical mobility and reactivity in soil systems. Proc. Amer. Soc. Agron. and Soil Sci. Symp., 29 Nov.-3 Dec. 1981.

Warncke, D.D. 1986. Analyzing greenhouse growth media by the saturation extraction method HortScience 21:223-225.

Warncke, D.D. and D.M. Krauskopf. 1983. Greenhouse growth media: Testing and nutrition guidelines. Michigan State Univ. Ext. Bul. E-1736.

Yelanich, M.V. and J.A. Biernbaum. 1993. Rootmedium nutrient concentration and growth of poinsettia at three fertilizer concentrations and four leaching fractions. J. Amer. Soc. Hort. Sci. 118:771-776. 